\title{
Branching Angles of Several Cocoa Genotypes and Their Effect on Determining Optimum Plant Spacing
}

\author{
Bayu Setyawan*1), Indah Anita-Sari ${ }^{1)}$, Fatrezza Ihsan²), Heksan Panua ${ }^{3)}$, and Agung Wahyu Susilo ${ }^{1)}$ \\ ${ }^{1)}$ Indonesian Coffee and Cocoa Research Institute, Jl. PB. Sudirman No. 90, Jember, Indonesia \\ ${ }^{2}$ School of Science and Biological Technology, Bandung Institute of Technology, Jl. Ganesa 10, Bandung, Indonesia \\ ${ }^{3)}$ Agrotechnology Department, Gorontalo State University, Wumialo, Kota Tengah, Gorontalo, Indonesia \\ ${ }^{*}$ Corresponding author: setyawanbayu45@gmail.com \\ Received: 13 July 2021 / Accepted: 26 October 2021
}

\begin{abstract}
Identification of the type of branching architecture will be one for the considerations in determining specific spacing recommendations for cocoa plantation. The research was conducted at Kaliwining Experimental Station, Indonesian Coffee and Cocoa Research Institute. The aim of this study was to investigate of branching angle characteristics of cocoa clones that can be used in determining planting space in cocoa farms. This research usied a completely randomized block design (RCBD) consisting of 21 genotypes as treatments. Each treatment was repeated three times and each replication consisted of three sample plants. Parameters observed were branch angle and the type of branching. Branch angle is the angle formed by the outermost primary branch and was measured using a protractor. The results showed that each genotype had a different angle on the primary branch, while the secondary and tertiary branch angles did not shown any significant difference. The results of the analysis showed that of the 21 genotypes tested, ICCRI 03, BAL 209, and KW 411 showed horizontal branching type; Sulawesi 01 and Sulawesi 03 showed vertical branching type, while the other 16 genotypes had intermediate branching types. Cocoa clones with a vertical branching type can be planted in denser spacing compared to cocoa clones with a horizontal branching type. The population per hectare of clones with vertical branching type can be increased 3 to 4 times when compared to clones with horizontal branching type.
\end{abstract}

Keywords: architecture, genotype, branching type, cocoa clone

\section{INTRODUCTION}

Cocoa production in Indonesia decreased every year (Ditjenbun, 2019). In addition to many old cocoa trees, one of the causes of the decline in cocoa production is limited productive land (Fahmid et al., 2018). Increasing cocoa production can be done through extensification and or intensification. The intensification program that can be carried out in limited land is to increase the optimum population of cocoa trees so as to increase productivity in units of area. Number of trees in the unit area of land is affected by the planting spacing (Olufemi et al., 2020). In general, cocoa plantation in Indonesia uses a planting distance of $3 \mathrm{~m} \times 3 \mathrm{~m}$ or $4 \mathrm{~m} \times 2 \mathrm{~m}$, consequenly that in one hectare cocoa plantation consists of approximately 1100 trees (Puslitkoka, 2015). The use of spacing is considered to be re-evaluated to optimize cocoa productivity per hectare. Efforts to increase cocoa productivity can be achieved by increasing the population of cocoa plants per hectare using a high-density population (HDP) system (Maharaj et al., 2003). Successful 
implementation of HDP can be achieved if the optimum spacing between cocoa plants is recoqnized. The spacing between cocoa plants affects the competition for cocoa plant growth factors such as water, nutrients, and light. In addition to this, planting spacing that are too dense also affect the increase in disease attacks due to fungal attacks because the microclimate environment of cocoa plantations is too humid. Therefore for HDP cocoa plantations, a cocoa genotype with dwarf growth is required (Souza et al., 2009). Specifications for optimum cacao spacing can be identified based on the type of branching of each cocoa genotype.

Genetics and environment are factors that influence plant architecture such as plant branching (Cai et al., 2016), while the genetic factors are controlled by many genes (MauroHerrera \& Doust, 2016). Two parameters that determine the role of branching type on light competition are the angle of branching and the length of branches formed by plants (Valladares \& Niinemets, 2007). In Indonesia, many superior cocoa clones have been released, but the recommendation for planting distance still uses a standard spacing of $3 \mathrm{~m} \mathrm{x} 3 \mathrm{~m}$. The use of spacing is indeed recommended for cocoa cultivation in general, but to increase cocoa productivity per unit area can be done by increasing the population of cocoa trees. The classification of clones with upright branching types needs to be done as a basis for grouping the types of cocoa clones that have the potential for the development of high dense population of cocoa cultivation. The aim of this study was to obtain information on the branching angle characteristics of cocoa clones that can be used in determining planting spacing in cocoa farms.

\section{MATERIALS AND METHODS}

The research was conducted at Kaliwining Experimental Station, of Indonesian Coffee and Cocoa Research Institute (ICCRI) in Jember, East Java, Indonesia. The research used a completely randomized block design (RCBD) consisting of 21 cocoa clones as treatments planted in 2015 with $3 \mathrm{~m} \mathrm{x} 3 \mathrm{~m}$ planting spacing. Each treatment was repeated three times and each replication consisted of three sample plants. The observations parameter were carried out on the branching type of cacao trees from 21 cocoa clones grafting using plagiotropic budwood. Shade trees in this location used seedless Leucaena sp. with $3 \mathrm{~m} \times 3 \mathrm{~m}$ planting spacing.

Determination of the branching character of cocoa plants was carried out referring to Susilo (2017) as a qualitative method by observing the branching type directly. The branching types of cocoa trees are divided into two, vertical branching if the average branching is moving upwards and horizontal if the average branching is going sideways (Figure 1). Engels (1980) sugests a quantitative method by observing the branching type directly. This method estimates the branching character by determining the angle between opposite branches on the primary branch using a protractor. If there is no branch with a center line, then draw an imaginary line to estimate the angles of the other branches. Primary branches are branches that grow from an upright trunk. If the angle is less than 90 degrees, then the branching type of the plant is upright. If the angle is more than 90 degrees but less than 135 degrees, then the type of tree branching is intermediate and if the angle is more than 135 degrees then the branching type is pendulous. In this study, quantitative observations were carried out by observing directly the angle of the primary, secondary and tertiary branches. 


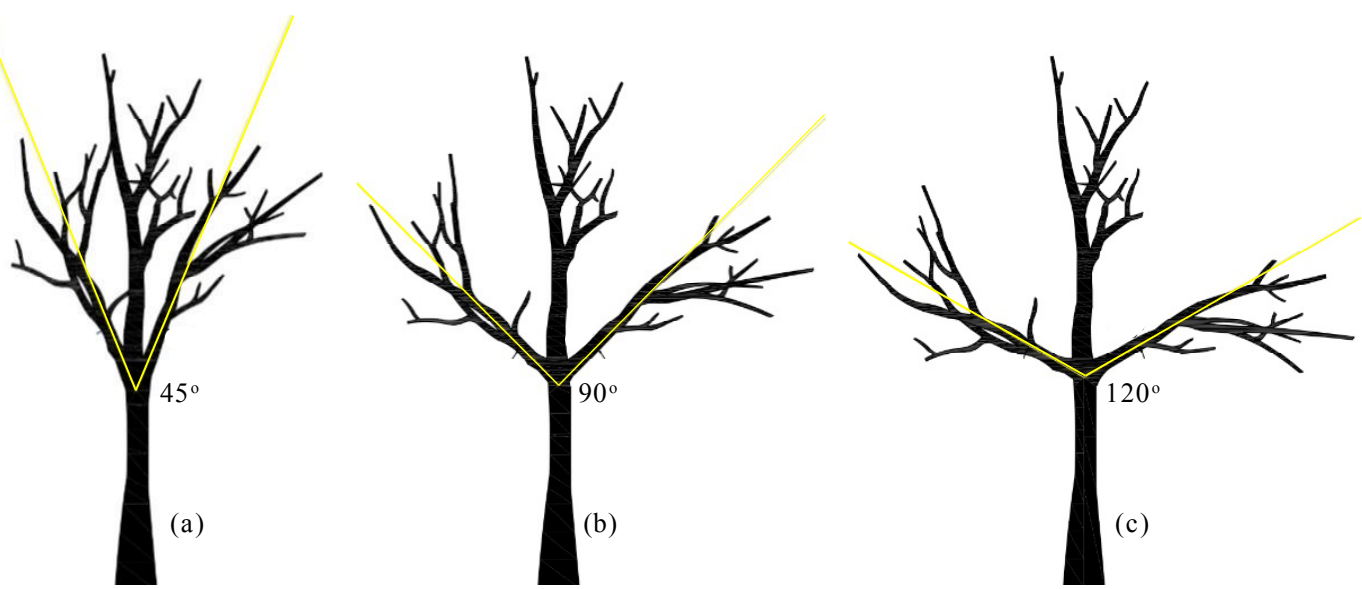

Figure 1. Visualization of branching type based on primary branch angle (a) vertical (about $45^{\circ}$ ), (b) intermediate (about $90^{\circ}$ ), and (c) horizontal (about $120^{\circ}$ )

Horizontal reach of the optimum primary branch of cocoa can be estimated using the Cosine function, with the input of the angle primary branch and the length of primary branch which is determined to be $1.50 \mathrm{~m}$. If the angle of the primary branch $=\theta$ and the length of the primary branch is $1.50 \mathrm{~m}$, then the horizontal reach of the primary

branch $(\mathrm{x})$
$=1.50 \cos \frac{180^{\circ}-\theta^{a}}{2}$

Data analysis was carried out by inference analysis by comparing whether there were differences between the branching angles in each branching order or not between branches of different types of plant architecture. If the branching angle data obtained are normality tested using Shapiro-Wilk analysis and homogeneity using Levene's Test, then a One-Way Anova analysis is performed for each tree architecture comparison, whereas if the data is abnormal, then a Kruskal-Wallis analysis is performed. To see the average of which tree architecture is different from the others, the Tukey post-hoc test was carried out. The level of confidence used in all the above analyzes is $95 \%$. After statistical analysis, data processing was carried out by representing the assumptions of the tree architecture in the form of images based on the type of architecture that has been found.

\section{RESULTS AND DISCUSSION}

Branching of a plant is one of the variables that determine the production of an individual or population of cocoa plants (Meneses-Buitrago et al., 2019). Meanwhile, branching characters such as branching angle and branching type are important to study to support plant production. The results of observations on the primary angle of branching formed by each clone showed significant differences (Table 1). The larger the primary angle formed by each clone, the closer it is to the horizontal type of branching. Clones with upright branching types have potentially to be used in the composition of denser cropping system $>1100$ plants.ha ${ }^{-1}$. The upright branching types reduce the planting distance where the overlap between branches can be narrowed and eventually the population can be highes (Govindaraj \& Jancirani, 2017). Secondary and tertiary branches were formed after the primary branches. The 21 cocoa genotypes tested for 
the formation of secondary and tertiary branches were relatively the same (Table 1). Secondary and tertiary branches affect production in relation to the number of branches formed. The more branches formed the more surface area for the flower grows to produce fruits. The clones with the largest primary branch angle were BAL 209 and ICCRI 03, while Sulawesi 01 had the smallest primary branch angle among the observed cocoa clones.

Based on the distribution of the primary branching angle data from 21 cocoa clones tested, they were grouped into three classes or types of branching, namely vertical $\left(45^{\circ}-\right.$ $\left.75^{\circ}\right)$, intermediate $\left(75^{\circ}-105^{\circ}\right)$, and horizontal $\left(105^{\circ}-180^{\circ}\right)$ (Table 2). ICCRI 03, KW 411, and BAL 209 were classified as genotypes that had a horizontal branching architecture type. Sulawesi 01 and Sulawesi 03 were classified as genotypes that had a vertical branching architecture type, whereas the others had an intermediate branching type. The formation of branches in a plant is influenced by force stress in the area after the branch collar which can cause branch bending if the part is not resistant to force stress so as to provide a flatter/horizontal visual plant architecture (Eisner et al., 2002). Therefore, the differences in tree architecture may be influenced by differences in branch strength of each genotypes. This difference in branch strength can be influenced by differences in size, density, constituent structure, while the branch bending factor are the presence of leaves, branches, flowers, fruits, or external factors (Shahbazi et al., 2015; James, 2003; Eisner et al., 2002). In cocoa cultivation ideally in one production area it is advisable to plant more than one genotype of cocoa, because cocoa trees have a low self-pollination rate, especially for bulk cocoa (Lanaud et al., 2017). Based on the results of the evaluation of the type of cocoa branching from each evaluated cocoa clone, it can also be used as a reference in determining the composition of clones in cocoa production based on the branching type group, such as plants with vertical branching types. It is better if vertical branches type is placed in one group to get the optimum population

Table 1. Branch angles of 21 genotypes of cocoa

\begin{tabular}{|c|c|c|c|}
\hline \multirow{2}{*}{ Clones } & \multicolumn{3}{|c|}{ Branches angle $\left(^{\circ}\right)$} \\
\hline & Primary & Secondary & Tertiary \\
\hline BAL 209 & $135.00 \mathrm{a}$ & $106.67 \mathrm{a}$ & $103.33 \mathrm{a}$ \\
\hline CRIOLLO & $80.00 \mathrm{bc}$ & $76.67 \mathrm{a}$ & $73.33 \mathrm{a}$ \\
\hline ICCRI 03 & $125.83 \mathrm{ab}$ & $102.50 \mathrm{a}$ & $82.50 \mathrm{a}$ \\
\hline ICCRI 09 & $86.67 \mathrm{abc}$ & $90.00 \mathrm{a}$ & $110.00 \mathrm{a}$ \\
\hline JTC 24 & $98.33 \mathrm{abc}$ & $96.67 \mathrm{a}$ & $90.00 \mathrm{a}$ \\
\hline KW 411 & $108.33 \mathrm{abc}$ & $93.33 \mathrm{a}$ & $86.67 \mathrm{a}$ \\
\hline KW 516 & $101.33 \mathrm{abc}$ & $92.33 \mathrm{a}$ & $101.00 \mathrm{a}$ \\
\hline KW 564 & $84.67 \mathrm{abc}$ & $90.33 \mathrm{a}$ & $100.00 \mathrm{a}$ \\
\hline KW 606 & $91.00 \mathrm{abc}$ & $85.00 \mathrm{a}$ & $72.33 \mathrm{a}$ \\
\hline KW 618 & $87.00 \mathrm{abc}$ & $105.00 \mathrm{a}$ & $97.67 \mathrm{a}$ \\
\hline KW 635 & $80.00 \mathrm{bc}$ & $78.33 \mathrm{a}$ & $76.67 \mathrm{a}$ \\
\hline KW 733 & $85.83 \mathrm{abc}$ & $120.00 \mathrm{a}$ & $92.50 \mathrm{a}$ \\
\hline KW 820 & $88.33 \mathrm{abc}$ & $85.67 \mathrm{a}$ & $110.00 \mathrm{a}$ \\
\hline KW 821 & $93.33 \mathrm{abc}$ & $93.33 \mathrm{a}$ & $90.00 \mathrm{a}$ \\
\hline KW 822 & $88.33 \mathrm{abc}$ & $86.67 \mathrm{a}$ & $83.33 \mathrm{a}$ \\
\hline PA 191 & $93.33 \mathrm{abc}$ & $100.83 \mathrm{a}$ & $107.50 \mathrm{a}$ \\
\hline SCA 6 & $96.67 \mathrm{abc}$ & $92.50 \mathrm{a}$ & $99.17 \mathrm{a}$ \\
\hline SCA 12 & $99.17 \mathrm{abc}$ & $104.17 \mathrm{a}$ & $125.83 \mathrm{a}$ \\
\hline SPA 9 & $85.00 \mathrm{abc}$ & $80.00 \mathrm{a}$ & $81.67 \mathrm{a}$ \\
\hline Sulawesi 01 & $68.33 \mathrm{c}$ & $80.83 \mathrm{a}$ & $109.17 \mathrm{a}$ \\
\hline Sulawesi 03 & $74.17 \mathrm{bc}$ & $98.33 \mathrm{a}$ & $82.50 \mathrm{a}$ \\
\hline
\end{tabular}


Branching angles of several cocoa genotypes and their effect on determining optimum plant spacing

Table 2. Classification of branching type by primary branching angle on 21 cocoa genotypes

\begin{tabular}{lcccc}
\hline Clone & $\begin{array}{c}\text { Primary } \\
\text { branch angle }\end{array}$ & $\begin{array}{c}\text { Branching type } \\
\text { (Susilo, 2017) }\end{array}$ & $\begin{array}{c}\text { Branching type } \\
\text { (Engels } \text { et al., 1980) }\end{array}$ & $\begin{array}{c}\text { Branching type } \\
\text { based on primary } \\
\text { angle class distribution }\end{array}$ \\
\hline ICCRI 03 & 125.83 & Horizontal & Intermediate & Horizontal \\
SCA 6 & 96.67 & Horizontal & Intermediate & Intermediate \\
SCA 12 & 99.17 & Horizontal & Intermediate & Intermediate \\
JTC 24 & 98.33 & Horizontal & Intermediate & Intermediate \\
KW 411 & 108.33 & Horizontal & Intermediate & Horizontal \\
BAL 209 & 135.00 & Horizontal & Intermediate & Horizontal \\
PA 191 193.33 & Vertical & Intermediate & Intermediate \\
KW 516 & 93.33 & Vertical & Intermediate & Intermediate \\
KW 606 & 101.31 Intermediate \\
KW 821 & 91.00 & Vertical & Intermediate & Inter \\
ICCRI 09 & 93.33 & Vertical & Intermediate & Intermediate \\
KW 733 & 86.67 & Vertical & Upright & Intermediate \\
Sulawesi 01 & 85.83 & Vertical & Upright & Intermediate \\
Sulawesi 03 & 68.33 & Vertical & Upright & Vertical \\
KW 618 & 74.17 & Vertical & Upright & Vertical \\
KW 635 & 87.00 & Vertical & Upright & Intermediate \\
KW 564 & 80.00 & Vertical & Upright & Intermediate \\
SPA 9 & 84.67 & Vertical & Upright & Intermediate \\
KW 820 & 85.00 & Vertical & Upright & Intermediate \\
CRIOLLO & 88.33 & Vertical & Upright & Intermediate \\
KW 822 & 80.00 & Vertical & Upright & Intermediate \\
\hline
\end{tabular}

on the available land area, by pay attention to the level of cross-pollination of each genotype. Plant architecture is defined as threedimensional organization of the plant body, includes the branching pattern, as well as the size, shape and position of leaves and flowers. Plant architecture has long been the only criterion for systematic and taxonomic classification, and, even today, it is the best means of identifying a plant species. Nonetheless it is also major agronomic importance which strongly influence the suitability of a plant for cultivation, yield and efficiency in harvesting (Reinhardt \& Kuhlemeier, 2002).

Based on the data analysis regarding the architectural differences of cocoa plants in 21 cocoa clones, visualization of the architectural types of vertical, intermediate, and horizontal cacao plants can be estimated. Visualization estimates are based on branch bending and primary branch angle differences. A visual estimate of the type of tree architecture can be seen in Figure 1. Based on the illustration of the branches formed, it can be estimated how many optimum cocoa trees can be planted per hectare. Determination of the optimum number of trees in addition to using the primary angle of the plant also considers the length of the primary branch formed. Ideally the length of the primary branch in cocoa is determined to be $1.50 \mathrm{~m}$ from the base of the stem formed at the formation of pruning (Puslitkoka, 2015). Therefore when the primary angle formed is maximum $\left(180^{\circ}\right)$ then the maximum reach of the primary branch is $1.50 \mathrm{~m}$.

Differences in the characteristic of branching type in cocoa genotypes can be considered in providing recommendations for optimal plant spacing. According to Valdhini \& Aini (2017), variations in spacing must be considered because spacing is one of the factors that affect the quality and quantity of plants. Plants with a wide canopy type retquire a larger spacing than plants with a vertical branching type. Using primary branching angle data, it is possible to estimate the optimum spacing and population per hectare for cocoa plants (Table 3 ). The 
Table 3. Estimation of optimum cocoa population based on primary branch angle

\begin{tabular}{lcccc}
\hline Primary branch angle $\left(^{\circ}\right)$ & $\begin{array}{c}\text { Branching } \\
\text { classification }\end{array}$ & $\begin{array}{c}\text { Primary } \\
\text { branch reach } \\
\text { horizontally }(\mathrm{m})\end{array}$ & $\begin{array}{c}\text { Plant } \\
\text { space }(\mathrm{m})\end{array}$ & $\begin{array}{c}\text { Estimated } \\
\text { cocoa trees } \\
\text { per ha }\end{array}$ \\
\hline 45 & vertical & 0.57 & 1.15 & 7500 \\
60 & vertical & 0.75 & 1.50 & 4400 \\
75 & intermediate & 0.91 & 1.83 & 2900 \\
90 & intermediate & 1.06 & 2.12 & 2200 \\
120 & horizontal & 1.30 & 2.60 & 1400 \\
180 & horizontal & 1.50 & 3.00 & 1100 \\
\hline Note $: *=$ rounding off population. & & & &
\end{tabular}

greater the angle of the primary branch, the less the population of cocoa plants per hectare. For cocoa clones that have vertical branching type the population per hectare can be increased more or less up to four times compared to the population of clones that have horizontaly branching types. Meanwhile clones with intermediate branching types, the population per hectare can be doubled.

In standard cocoa cultivation, it is not possible to only use information based on the branching characteristics. However, it is also necessary to consider other aspects such as leaf distribution and crown shape which are directly related to light transmission, $\mathrm{CO}_{2}$ exchange and related to other cultivation input factors. Plants with a wide canopy arrangement require a wide spacing while plants with a high crown arrangement require a narrower spacing. The expression of the main components of plant architecture that determine the shape of the crown and distribution of leaves will affect the transmission of light, $\mathrm{CO}_{2}$ exchange, and rainwater between the parts above the ground. The expression of the main components of tree architecture determines the shape of the canopy and the distribution of leaves affects the transmission of light, $\mathrm{CO}_{2}$ exchange and rainwater between the above-ground parts of the plant (Murniati, 2010).

\section{CONCLUSIONS}

The different types of branching of cocoa plants are determined by the magnitude of the angle of primary branch, however they are not influenced by the magnitude of the angle of the secondary and tertiary branches. ICCRI 03, BAL 209, and KW 411 have horizontal branching types, while Sulawesi 01 and Sulawesi 03 have vertical branching types. Cocoa clones with a vertical branching type can be planted using closer spacing than cocoa clones with a horizontal branching type. The population per hectare of clones with vertical branching type can be increased 3 to 4 times compared to clones with horizontal branching type.

\section{REFERENCES}

Cai, G.; Q. Yang; H. Chen; Q. Yang; C. Zhang; C. Fan \& Y. Zhou (2016). Genetic dissection of plant architecture and yield-related traits in Brassica napus. Scientific Reports, $6,1-16$.

Ditjenbun (2019). Statistik Perkebunan Indonesia Komoditas Kakao Tahun 20182020. Direktorat Jenderal Tanaman Perkebunan, Jakarta.

Eisner, N.J., E.F. Gilman \& J.C. Grabosky (2002). Branch morphology impacts compartmentalization of pruning woods. Journal of Arboriculture, 2(28), 99-105. 
Engels, J.M.M. (1980). Cacao descriptors, their states and modus operandi. Turrialba, 28(2), 209-218.

Fahmid, I.M.; H. Harun; M.M. Fahmid; Saadah $\&$ N. Busthanul (2018). Competitiveness, production, and productivity of cocoa in Indonesia. IOP Conference Series: Earth and Environmental Science, 157 012067.

Givindaraj, K. \& P. Jancirani (2017). Effect of pruning on cocoa (Theobroma cacao L.) on morphological, flowering and yield and quality of cocoa beans. International Journal of Agricultural Research, 7(6), 113-118.

Lanaud, C.; O. Fouet; T. Legavre; U. Lopes; O. Sounigo; M.C. Eyango; B. Mermaz; M.R. Da Silva; R.G.L. Solorzano; X. Argout; G. Gyapay; H.E. Ebaiarrey; K. Cologes; C. Sanier; R. Ricallan; G. Mastin; N. Cryer; M. Boccara; J. Verdeil; I.B.E. Mousseni; K.P. Gramacho \& D. Clément (2017). Deciphering the Theobroma cacao selfincopatibility system: From genomics to diagnostic markers for self-compatibility. Journal of Experimental Botany, 68(17), 4775-4790.

Maharaj, K.; T. Indalsingh; D. Ramnath \& A. Cumberbatch (2003). High density planting of cacao: The Trinidad and Tobago experience. International Workshop on Cocoa Breeding for Improved Production System, Accra, Ghana.

Mauro-Herrera, M. \& A.N. Doust (2016). Development and genetic control of plant architecture and biomass in the panicoid grass, setaria. PLoS ONE, 11(3), 1-27.

Meneses-Buitrago, D.H.; M.M. BolañosBenavides; L.F. Gómez-Gil; H.S. RamosZambrano (2019). Evaluation of irrigation and pruning on the phenology and yield of Theobroma cacao L. Agronomía Mesoamericana, 30(3), 681-693.
Murniati (2010). Arsitektur pohon, distribusi perakaran, dan pendugaan biomassa pohon dalam sistem agroforestry. Jurnal Penelitian Hutan dan Konservasi Alam, VII (2), 103-117.

Olufemi, A.K.; F.A. Olatunde; A.S. Adewale; I. Mohammed; U. Osasogie; A.F. Efe \& O.F. Adeyemi (2020). Effect of density planting on the vigour and yield of Theobroma cacao L. in the Southwest of Nigeria. World Journal of Advanced Research and Reviews, 08(01), 217-223.

Puslitkoka (2015). Pedoman Teknis Budidaya Tanaman Kakao. Pusat Penelitian Kopi dan Kakao Indonesia, Jember.

Reinhardt, D. \& C. Kuhlemeier (2002). Plant architecture. Embo Reports, 3(9), 846-851.

Shahbazi, Z.; A. Kaminski \& L. Evans (2015). Mechanical stress analysis of tree branches. American Journal of Mechanical Engineering, 3(2), 32-40.

Souza, C.A.S.; L.A.S. Dias; M.A.G. Aguilar; S. Sonegheti; J. Oliveira \& J.L.A. Costa (2009). Cacao yield in different planting densities. Brazil Arch. Biol. Technol, 52(6), 1313-1320.

Susilo, A.W. (2017). Pedoman Teknis: Pengelolaan Plasma Nutfah Kakao (Theobroma cacao L.). Pusat Penelitian Kopi dan Kakao Indonesia. Jember, Indonesia.

Valdhini, I.Y. \& N. Aini (2017). Pengaruh jarak tanam dan varietas pada pertumbuhan dan hasil tanaman sawi putih (Brassica chinensis L.) secara hidroponik. Plantropica, 2(1), 39-46.

Valladares, F. \& U. Niinemets (2007). The architecture of plant crowns: from design rules to light capture and performance. In: Functional Plant Ecology (F. Pugnaire \& F. Valladeres, Eds.). Taylor and Francis, New York. 